\title{
Enhanced Glucagon Secretion by Pancreatic Islets from Prednisolone-Treated Mice*
}

\author{
J. Marco, C. Calle, J.A. Hedo and M.L. Villanueva \\ Clínica Puerta de Hierro, Universidad Autónoma de Madrid, Madrid, Spain
}

Summary. This work was undertaken to study the effect of prednisolone on glucagon release in mouse pancreatic islets isolated by the collagenase technique. Pretreatment of the donors with prednisolone $(0.2-0.3 \mathrm{mg}$ daily) induced an increase in glucagon release both in the absence $(1005 \pm 75$, SEM, vs. $796 \pm 46 \mathrm{pg} / 10$ islets $/ 60 \mathrm{~min}, \mathrm{p}=0.019)$ and in the presence of $7.5 \mathrm{mM}$ arginine ( $1500 \pm 119$ vs. $1236 \pm 61$ $\mathrm{pg} / 10$ islets $/ 60 \mathrm{~min}, \mathrm{p}=0.05$ ). The glucagon content of the islets was not modified by the treatment ( $28.6 \pm 1.1 \mathrm{vs.} 28.0 \pm 1.1 \mathrm{ng} / 50$ islets). The addition of prednisolone $\left(5 \cdot 10^{-5} \mathrm{M}\right)$ into the medium, failed to affect significantly glucagon secretion. In agreement with previous human studies, our data indicate that chronic glucocorticoid administration augments the secretory activity of the A-cell. This does not seem to be a result of increased glucagon synthesis nor a direct effect of glucocorticoids on the glucagon-releasing mechanism. Rather, environmental changes induced by these hormones could be responsible for A-cell hyperfunction.

Key words: Mouse pancreatic islets, incubation, prednisolone, glucagon, insulin, release.

\footnotetext{
* Presented at the 11th Annual Meeting of the European Association for the Study of Diabetes, September 4, 1975, Munich, Federal Republic of Germany (Abstract \# 32, Diabetologia 11, 334, 1975).

Supported in part by a research grant (12-895-74) from the Instituto Nacional de Previsión, Spain, by a research contract (No. 1551/RB) from the International Atomic Energy Agency, Vienna, Austria, and by a gift from the Alexander von Humboldt Stiftung, Bonn-Bad Godesberg, Federal Republic of Germany.
}

Previous work from our laboratory has demonstrated that prednisolone treatment enhances basal and arginine-provoked glucagon secretion in man [1]. This finding has been confirmed by Wise et al. [2] with another glucocorticoid - dexamethasone - and using alanine or the ingestion of a protein meal as glucagon secretagogues.

To gain further insight into the influence of glucocorticoids on A-cell function, we have studied the release of glucagon ("basal" and arginine-stimulated) in pancreatic islets obtained from prednisolonetreated mice. In addition, the effect of adding prednisolone to the incubation medium on glucagon secretion was also examined.

It was found that the islets harvested from pretreated donors secreted more glucagon than those from the controls, while prednisolone failed to affect directly glucagon release.

\section{Materials and Methods}

Four week old Swiss male mice from our inbred colony were used as pancreas donors. They were maintained on a standard diet (Sanders) and water "ad libitum", and fasted for $14 \mathrm{~h}$ prior to the experiments. Some groups of animals were treated with prednisolone (Solu-Dacortin H, 0.2-0.3 mg daily, for four days), administered in their drinking water. Previous calculations had shown that the average daily water intake for the treated mice was $5.03 \pm 0.07(\mathrm{SEM}) / \mathrm{ml}$, and $4.25 \pm 0.14 / \mathrm{ml}$ for the controls.

The islets were isolated by the collagenase technique [3], as modified by Coll-García and Gill [4]. In each experiment a pool of eight pancreata was employed. Batches of 10 islets were incubated for 60 or 180 minutes in two $\mathrm{ml}$ of a bicarbonate-buffered salt 


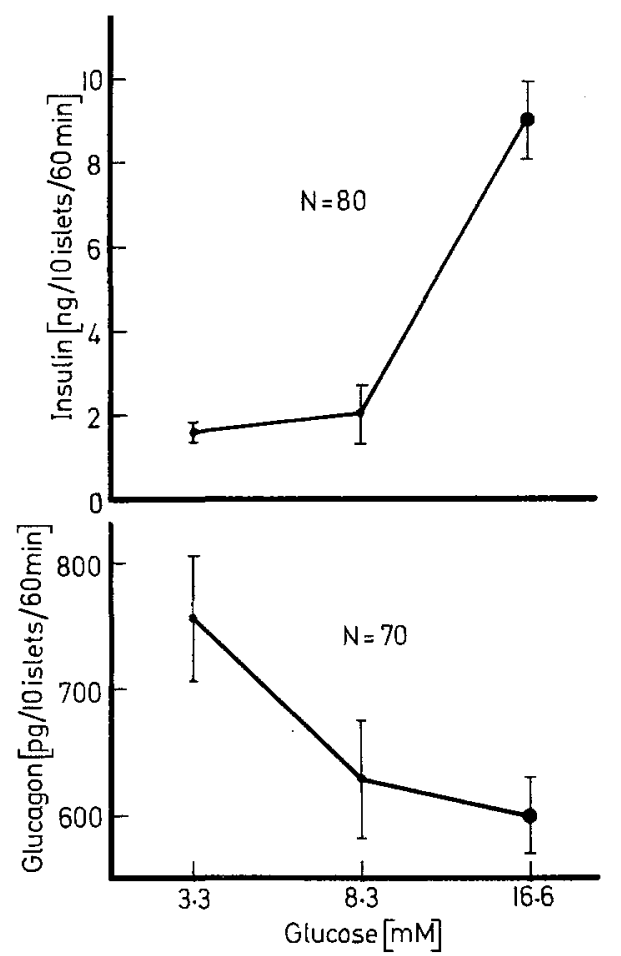

Fig. 1. Effect of glucose on glucagon and insulin release by mouse pancreatic islets (Mean \pm SEM; $\mathbf{N}=$ number of incubation vials). The large dots represent statistically significant differences from the $3.3 \mathrm{mM}$ glucose value

solution [5] (gas phase $95: 5, \mathrm{O}_{2}: \mathrm{CO}_{2}$ ) containing $0.2 \%$ bovine albumin (Cohn fraction V), $2000 \mathrm{U}$ of kallikrein-trypsin inhibitor (Trasylol), and $3.3 \mathrm{mM}$ glucose. Conventionally, this solution will be referred to as "basal medium" throughout the text. Arginine hydrochloride ( 7.5 or $10 \mathrm{mM}$ ) was used as glucagon secretagogue; other additions were made as described in the appropriate figures. All incubations were performed in a shaking water bath at $37^{\circ} \mathrm{C}$ and 60 strokes per minute. At the end of the incubation, an aliquot of each sample was diluted $1: 4$ in $0.2 \mathrm{M}$ glycine, containing $0.25 \%$ human albumin and $1 \%$ normal sheep serum $(\mathrm{pH} 8.8)$, and immediately frozen at $-20^{\circ} \mathrm{C}$ until the time of analysis, not more than four weeks later.

To determine the glucagon and insulin content of the islets, groups of 50 were placed in one $\mathrm{ml}$ of $0.2 \mathrm{M}$ glycine ( $\mathrm{pH} 8.8$ ) and subjected to sonication (80 seconds at 50 watts on a Sonifier Cell Disruptor W140). The aliquots containing the disrupted islets were diluted $1: 4$ in 0.2 glycine with $0.25 \%$ human albumin, $1 \%$ normal sheep serum and $2000 \mathrm{U} / \mathrm{ml}$ of Trasylol (pH 8.8), and immediately frozen at $-20^{\circ} \mathrm{C}$ until the time of analysis.

Radioimmunoassay was used to estimate gluca-

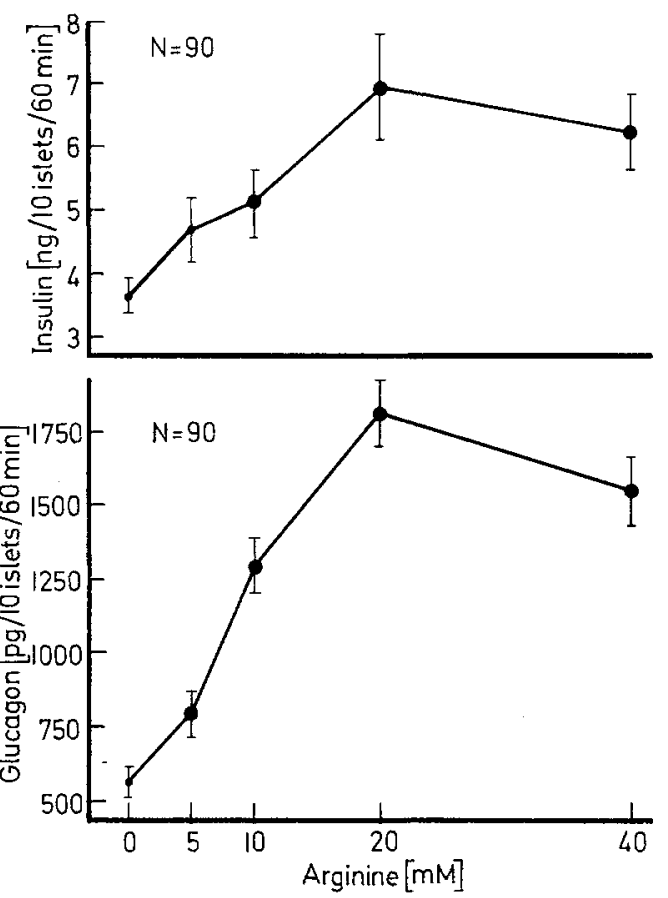

Fig. 2. Effect of arginine on glucagon and insulin release by mouse pancreatic islets (Mean $\pm S E M ; N=$ number of incubation vials). The large dots represent statistically significant differences from the 0 arginine value

gon [6] ${ }^{1}$ and insulin [7]. Beef-pork glucagon (Eli Lilly) was iodinated, according to Hunter and Greenwood [8], and was also used as the standard. Porcine insulin (Novo) was used for iodination, and mouse insulin (Novo) for the standard curve. Protein determination was carried out by the method of Lowry et al. [9]. In the figures, $\mathrm{N}$ corresponds to the number of incubated flasks for each point and results are expressed as means \pm SEM. Differences between values were tested for significance by unpaired $\mathrm{t}$-test analysis.

The secretory activity of our preparation was assessed by testing the capability of the islets to release insulin and glucagon in response to glucose and to arginine. As depicted in Figure 1, an increase in the glucose concentration of the medium was associated with greater insulin output and reduced glucagon release. The suppressor effect of glucose on glucagon secretion became apparent by augmenting glucose molarity from $3.3 \mathrm{mM}$ to $8.3 \mathrm{mM}$ (758 \pm 51 to $631 \pm$ $46 \mathrm{pg} / 10$ islets $/ 60 \mathrm{~min}, \mathrm{p}=0.072)$ and was statistically significant at $16.6 \mathrm{mM}(601 \pm 34 \mathrm{pg} / 10$ islets $/ 60$ $\min , \mathrm{p}=0.014$ vs. $3.3 \mathrm{mM}$ glucose). Figure 2 shows

\footnotetext{
1 Glucagon antiserum $30 \mathrm{~K}$ was a generous gift from Dr. R. H. Unger
} 


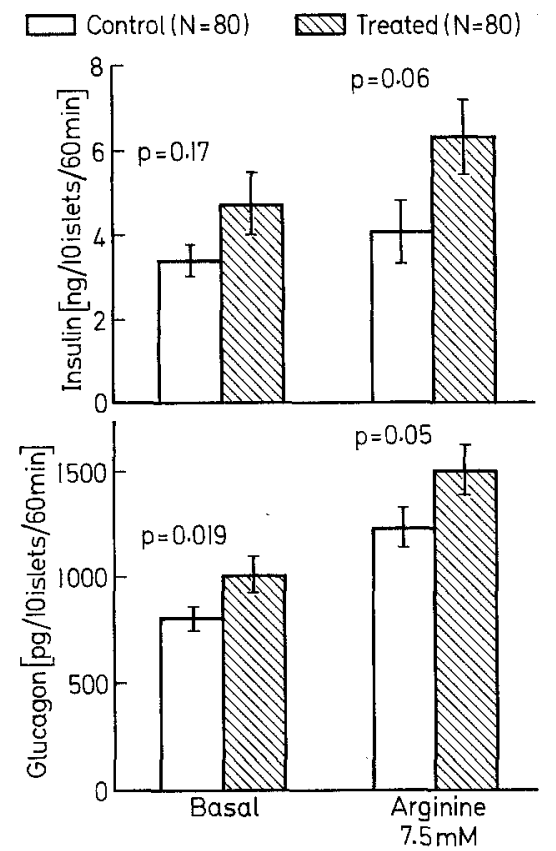

Fig. 3. Glucagon and insulin release by pancreatic islets obtained from prednisolone-treated mice (Mean $\pm \mathrm{SEM} ; \mathrm{N}=$ number of incubation vials)

the dose-response curves of insulin and glucagon elicited by arginine. The secretory rate of both hormones showed a linear pattern from 0 to $20 \mathrm{mM}$ arginine. At this concentration, maximal outputs for glucagon (327\% of the value corresponding to the basal medium) and insulin (190\% of the basal medium) were found.

\section{Results}

Effect of Prednisolone Pretreatment on Glucagon and Insulin Release by Mouse Pancreatic Islets

The islets obtained from pretreated donors secreted more glucagon than the controls, both in the basal medium (1005 \pm 75 vs. $796 \pm 46 \mathrm{pg} / 10$ islets $/ 60 \mathrm{~min}$, $\mathrm{p}=0.019)$ and in the presence of arginine $(1500 \pm$ 119 vs. $1236 \pm 61 \mathrm{pg} / 10$ islets $/ 60 \mathrm{~min}, \mathrm{p}=0.05$ ) (Fig. $3)$. Insulin release was also augmented, although the differences did not attain the five per cent level of statistical significance $(4.5 \pm 0.7$ vs. $3.4 \pm 0.3 \mathrm{ng} / 10$ islets $/ 60 \mathrm{~min}, \mathrm{p}=0.17$ in the basal medium $; 6.3 \pm 0.9$ vs. $4.0 \pm 0.7 \mathrm{ng} / 10$ islets $/ 60 \mathrm{~min}, \mathrm{p}=0.06$, in the presence of arginine).

Glucagon and Insulin Content of Pancreatic Islets from Prednisolone-Treated Mice

Prednisolone treatment failed to alter significantly the amount of glucagon and insulin content in the islets,

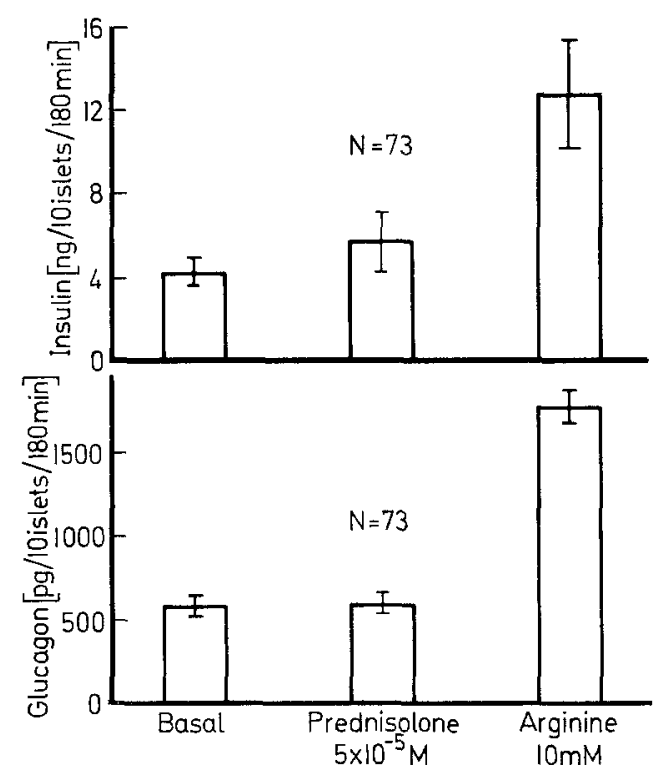

Fig. 4. Effect of the addition of prednisolone into the incubation medium on glucagon and insulin release by mouse pancreatic islets (Mean $\pm \mathrm{SEM} ; \mathrm{N}=$ number of incubation vials). Arginine was used as a control secretagogue

Table 1. Glucagon and insulin content of pancreatic islets from prednisolone-treated mice (Mean $\pm \mathrm{SEM} ; \mathrm{N}=$ number of incubation vials)

\begin{tabular}{llll}
\hline & $\begin{array}{l}\text { Glucagon } \\
(\mathrm{ng} / 50 \text { islets })\end{array}$ & $\begin{array}{l}\text { Insulin } \\
(\mathrm{ng} / 50 \text { islets })\end{array}$ & $\begin{array}{l}\text { Protein } \\
(\mu \mathrm{g} / 50 \text { islets })\end{array}$ \\
\hline $\begin{array}{l}\text { Control } \\
(\mathrm{N}=58)\end{array}$ & $28.6 \pm 1.1$ & $775 \pm 16$ & $21.3 \pm 0.8$ \\
$\begin{array}{l}\text { Treated } \\
(\mathrm{N}=64)\end{array}$ & $28.0 \pm 1.1$ & $842 \pm 34$ & $26.6 \pm 1.0$ \\
$\mathrm{P}$ & $\mathrm{NS}$ & $\mathrm{NS}$ & 0.0002 \\
\hline
\end{tabular}

while their protein content was found to be augmented, about 25 per cent (Table 1).

Glucagon and Insulin Release by Mouse Pancreatic Islets Incubated in the Presence of Prednisolone

When prednisolone was incorporated into the medium $\left(5 \cdot 10^{-5} \mathrm{M}\right)$, glucagon release was almost identical to the control experiments ( $594 \pm 68$ vs. 584 $\pm 67 \mathrm{pg} / 10$ islets/180 min) (Fig. 4). A small, but not significant, increase of insulin output was found (5.84 \pm 1.4 vs. $4.28 \pm 0.7 \mathrm{ng} / 10$ islets $/ 180 \mathrm{~min}, \mathrm{p}=0.33$ ). In another series of incubations $(\mathrm{N}=56)$, prednisolone also failed to significantly modify argininestimulated glucagon $(1060 \pm 61$ vs. $1035 \pm 67 \mathrm{pg} / 10$ islets $/ 180 \mathrm{~min})$ and insulin secretion (6.9 \pm 0.8 vs. 6.7 $\pm 0.8 \mathrm{ng} / 10$ islets $/ 180 \mathrm{~min}$ ). 


\section{Discussion}

The incubation of isolated mouse pancreatic islets has been proven to be a reliable model to study simultaneously glucagon and insulin release. In a recent study [10] collagenase treatment induced subtle damage of the A and B-cells, reflected by a loss in their sensitivity to known inhibiting agents, such as glucose and somatostatin. However, in our system the release of glucagon was significantly lowered - by 21 per cent - when the glucose concentration of the medium was increased from $3.3 \mathrm{mM}$ to $16.6 \mathrm{mM}$. On the other hand, arginine was an effective secretagogue of Aand B-cells. At $3.3 \mathrm{mM}$ glucose, this amino acid was a more potent stimulus for glucagon than for insulin release.

In agreement with our previous human studies [1], the islets obtained from prednisolone-treated mice released more glucagon than the controls. Glucagon hypersecretion was demonstrated when the islets were incubated in the basal medium and in the presence of arginine. However, the addition of prednisolone in a high concentration $\left(5 \cdot 10^{-5} \mathrm{M}\right)$ into the incubation medium was ineffective in altering basal and arginineprovoked glucagon release. This finding is in accordance with the observation that the intravenous administration of a large dose $(100 \mathrm{mg}$ ) of this corticoid, capable of inducing a rise in glycaemia, failed to modify the levels of circulating glucagon in normal subjects [1]. It should be mentioned that in these experiments the incubation of the islets was maintained for 180 minutes, a time period which is considered adequate for glucocorticoids to exert their biological activity "in vitro", such as induction of tyrosine transaminase in fetal rat liver explants [11], stimulation of lipolysis in rat parametrial and mesenteric adipose tissue [12], and inhibition of incorporation of precursors into nucleic acids and protein of rat thymocytes [13]. Nevertheless, it cannot be ruled out that the failure of prednisolone to influence glucagon release might be due to insufficient exposure of the islets to this steroid.

On the other hand, the glucagon content of the islets from prednisolone-treated mice was indistinguishable from that corresponding to the controls. However, as an index of corticoid activity, their amount of protein was found to be increased, which is in agreement with the hypertrophy of islet tissue observed after chronic glucocorticoid administration $[14,15]$.

Therefore the enhancement of the secretory activity of the A-cell observed in pancreatic islets from prednisolone-treated mice does not seem to be a consequence of increased glucagon synthesis nor a direct effect of this corticoid on the glucagon-releasing mechanism. As previously postulated [1], changes in the milieu intérieur subsequent to chronic glucocorticoid administration may be considered responsible for A-cell hyperfunction.

Concerning the influence of prednisolone on B-cell function, the insulin secretory rate (basal and arginine-stimulated) of islets from mice treated with this steroid was greater than that of the controls, although not significantly. Malaisse et al. [16], working on a preparation of rat pancreas pieces, also found that cortisol pretreatment of the donors resulted in an increase in insulin output; in their experiments, using $8.3 \mathrm{mM}$ glucose, the difference was statistically significant. In our experience, the incorporation of prednisolone into the incubation medium failed to modify significantly insulin release, and prednisolone pretreatment of the mice did not alter the insulin content of their islets. These results agree with those of the aforementioned authors, obtained in similar experiments. Thus, a direct effect of glucocorticoids on insulin secretion is not supported by the current "in vitro" studies.

Acknowledgments. We wish to thank Dr. V. Arias Paz (Novo, Spain) and Dr. R. Chance (Eli Lilly, U.S.A.) for their generous supply of beef-pork glucagon, porcine insulin and mouse insulin. The expert technical assistance of Ms. Ana Ramírez, Ms. Inés GarcíaMuñoz and Ms. Begoña Samper is gratefully acknowledged.

\section{References}

1. Marco, J., Calle, C., Román, D., Díaz-Fierros, M., Villanueva, M.L., Valverde, I.: Hyperglucagonism induced by glucocorticoid treatment in man. New Engl. J. Med. 288, 128-131 (1973)

2. Wise, J.K., Hendler, R., Felig, P.: Influence of glucocorticoids on glucagon secretion and plasma amino acid concentrations in man. J. clin. Invest. 52, 2774-2782 (1973)

3. Lacy, P.E., Kostianovsky, M.: Method for the isolation of intact islets of Langerhans from the rat pancreas. Diabetes 16, 35-39 (1967)

4. Coll-García, E., Gill, J. R.: Insulin release by isolated pancreatic islets of the mouse incubated "in vitro". Diabetologia 5 , 61-66 (1969)

5. Krebs, H.A., Henseleit, K.: Untersuchungen über die Harnstoffbildung im Tierkörper. Hoppe-Seylers Z. physiol. Chem. 210, 33-66 (1932)

6. Faloona, G.R., Unger, R. H.: Glucagon. In: Methods of hormone radioimmunoassay (eds. B.M. Jaffe, H. R. Behrman), pp. 317-330. New York: Academic Press, Inc. 1974

7. Herbert, V., Lau, K.-S., Gottlieb, C. W., Bleicher, S.J.: Coated charcoal immunoassay of insulin. J. clin. Endocr. 25, 1375-1384 (1965)

8. Hunter, W.M., Greenwood, F.C.: Preparation of iodine-131 labelled human growth hormone of high specific activity. Nature (Lond.) 194, 495-496 (1962) 
9. Lowry, O.H., Rosenborough, N. J., Farr, A.L., Randall, R. J.: Protein measurement with the Folin phenol reagent. J. biol. Chem. 193, 265-275 (1951)

10. Norfleet, W.T., Pagliara, A.S., Haymond, M.W., Matchinsky, F.M.: Comparison of alpha- and beta-cell secretory responses in islets isolated with collagenase and in the isolated perfused pancreas of rats. Diabetes 24, 961-970 (1975)

11. Wicks, W.D.: Induction of hepatic enzymes by adenosine $3^{\prime}$, 5 '-monophosphate in organ culture. J. biol. Chem. 244, 3941-3950 (1969)

12. Fain, J.N., Scow, R.O., Chernick, S.S.: Effects of glucocorticoids on metabolism of adipose tissue "in vitro". J. biol. Chem. 238, 54-58 (1963)

13. Makman, M.H., Dvorkin, B., White, A.: Alterations in protein and nucleic acid metabolism of thymocytes produced by adrenal steroids "in vitro". J. biol. Chem. 241, 1646-1648 (1966)

14. Volk, B.W., Lazarus, S.S.: Ultramicroscopic studies of rabbit pancreas during cortisone treatment. Diabetes 12, 162-173 (1963)
15. Gepts, W., Toussaint, D.: Effect of cortisone, growth hormone and hypophysectomy on the enzymatic activity of the pancreatic islets. In: The structure and metabolism of the pancreatic islets (eds. S.E. Brolin, B. Hellman, H. Knutsson), pp. 357-377. Oxford: Pergamon Press 1964

16. Malaisse, W.J., Malaisse-Lagae, F., McCraw, E.F., Wright, P.H.: Insulin secretion "in vitro" by pancreatic tissue from normal, adrenalectomized and cortisol-treated rats. Proc. Soc. exp. Biol. (N.Y.) 124, 924-928 (1967)

Received: November 4, 1975, and in revised form: April 26, 1976

Dr. J. Marco

Clínica Puerta de Hierro

Universidad Autónoma de Madrid

San Martín de Porres 4

Madrid 35

Spain 